\title{
Potensi Laju Erosi Das Waduk Randugunting Menggunakan Metode USLE
}

\author{
Rigel Putra Samudera ${ }^{1}$, Muhammad Genta ${ }^{2}$, \\ Budi Santosa ${ }^{3}$, Djoko Suwarno ${ }^{4}$ \\ email: ${ }^{1}$ rigelputra123@gmail.com, ${ }^{2}$ muhammadgw@gmail.com \\ Program Studi Teknik Sipil, Fakultas Teknik, Unika Soegijapranata, Semarang, Universitas Katolik \\ Soegijapranata; Jl. Pawiyatan Luhur IV/1 Bendan Dhuwur Semarang 50234, 024-8441555
}

\begin{abstract}
Abstrak
DAS merupakan daerah sebagai daerah tangkapan hujan yang rentan terhadap erosi yang dapat mengakibatkan permaslaahan pada sedimentasi Waduk. Besarnya sedimentasi yang terus meningkat dapat mempengaruhi kinerja waduk. Tujuan penelitian ini adalah menadapatkan nilai laju erosi menggunakan metode USLE (Universal Soil Loss Equation) dan sedimentasi pada DAS, serta membuat peta kriteria sebaran erosi DAS Waduk Randuguting dari tahun 2010 hingga 2019 dibantu dengan sistem informasi geografis (SIG) berupa Arc-Gis. Pada metode USLE dibutuhkan beberapa parameter seperti faktor erosivitas hujan (R), faktor erodibilitas tanah (K), faktor panjang dan kemiringan lereng (LS), dan faktor penggunaan lahan dan pengolahan tanah (CP).

Hasil dari penelitian ini didapatkannya nilai laju erosi DAS Waduk Randugunting tertinggi pada tahun 2014 sebesar 153.848 ton/ha dengan klasifikasi tingkat bahaya erosi sedang, dan terendah pada tahun 2012 sebesar 58.672 ton/ha dengan klasifikasi tingkat bahaya erosi ringan. Selain itu, didapatkan pula peta kriteria berupa peta sebaran erosi DAS Waduk Randugunting dari tahun 2010 hingga 2019. Berdasarkan nilai laju erosi didapatkan sediment yield sebesar 7705.682 ton/ha dan didapatkanpula umur layanan Waduk Randugunting yaitu 35 tahun.
\end{abstract}

Kata kunci : Erosi, USLE, Sedimentasi

\begin{abstract}
The watershed is an area as rain catchment is susceptible of erosion, and can bring an impact to reservoir sedimentation. The amount of sedimentation will increase dan it's impact to reservoir operation. The purpose of this research is to get estimated value of erosion with USLE (Universal Soil Loss Equation) method, reservoir sedimentation, and to make a criteria erosion map of Randugunting Reservoir Watershed from 2010 to 2019 asisted with Geographic Information System (SIG) in the form of Arc-Gis.The USLE method requires several paramaters such as the Rain Erosivity Rain (R), Soil Erodibility Factor (K), Slope Length and Slope Factor (LS), and Land Use and Tillage Factor $(\mathrm{CP})$.

The results of this research are the value of erosion rates of Randugunting Reservoir Watershed with the highest was in 2014 at 153.848 ton/ha with moderate erosion classification, and the lowes was in 2012 at 58.672 ton/ha with light erosion classification. Beside that, a criteria map was also obtained in the form of erosion map of Randugunting Reservoir Watershed from 2010 to 2019. Based on erosion rates, obtained the amount of sedimment yield is 7705.682 ton/ha and also obtainded that Randugunting Reservoir service life is 35 years.
\end{abstract}

Keywords: Erosion, USLE, and Sedimentation 


\section{PENDAhuluan}

Pada setiap musimnya di Indonesia memiliki masalah berkaitan dengan air. Saat musim hujan beberapa wilayah di Indonesia mengalami banjir, tanah longsor, dan erosi akibat intensitas hujan tinggi (BMKG, 2019). Selain itu, saat musim kemarau beberapa wilayah di Indonesia mengalami kekeringan yang berakibat pada kekurangan air bersih, air irigasi, dan air minum (BMKG, 2019). Salah satu upaya yang dapat dilakukan untuk mengatasi permasalahan air pada setiap musimnya di Indonesia dengan pembangunan waduk/bendungan.

Permasalahan pada waduk umumnya diakibakan oleh sedimentasi yang besar. Contoh waduk sedimentasi besar yaitu waduk gajah mungkur di wonogiri, Jawa Tengan memiliki sedimentasi sebesar 6 juta $\mathrm{m} 3$ pada tahun 2016, akibat erosi pada DAS memberi dampak pendangkalan pada area intake untuk suplai PLTA dan Irigasi (DetikNews, 2016). Sedangkan waduk selorejo di Malang, Jawa Timur memiliki sedimentasi sebesar 3.223.797,64 m3 tahun 2014 disebabkan adanya erosi pada DAS. Adanya erosi tersebut memberi dampak pada kapasitas tambungan mati yang telah direncanakan, (setyono dan Ismijayanti, 2015). Berdasarkan contoh waduk-waduk tersebut salah satu faktor yang mempengaruhi sedimentasi pada waduk yaitu erosi pada DAS.

Pada DAS randugunting memiliki sungai utama yaitu sungai randugunting. Pada das randugunting sedang dibangun waduk randugunting guna memenuhi kebutuhan air bersih, dan air irigasi di sekitas DAS. Dalam pembangunannya diperlukan analisis untuk mengetahui potensi laju erosi pada DAS yang dapat berimbas pada sedimentasi waduk.

\section{TINJAUAN PUSTAKA}

Erosi merupakan pengkisan atau lepasnya tanah yang diakibatkan adanya desakan-desakan seperti air dan angin dengan proses berlangsung yang terjadi seara alamiah ataupun berasal dari tindakan yang dilakukan manusia. Saat terjadinya erosi terdapat partikel-partikel tanah yang terkelupas dala satuan waktu yang dapat berupa detik, menit, jam, hari, tahun, dalam hal ini disebut laju erosi.

\section{Metode USLE (Universal Soil Loss Equation)}

Metode USLE (Universal Soil Loss Equation) merupakan permodelan untuk memperhitungkan kehilangan tanah (erosi) yang dikemukakan oleh wichmeier dan smith tahun 1978 yang dimana pengukuran dilakukan berdasarkan faktorfaktor yang mempengaruhi erosi berupa curah hujan, tipe dan jenis tanah, panjang dan kemiringan leeng, penutup permukaan tanah. Berdasarkan faktor-faktor tersebut kemudian dapat dilakukan perhitungan erosi dengan menggunakan persamaan USLE sebagai berikut:

$\mathrm{Ea}=\mathrm{R} \times \mathrm{K} \times \mathrm{LS} \times \mathrm{CP}$

Keterangan:

$\mathrm{Ea}=$ Laju erosi rata-rata tahunan (ton/ha/th).

$\mathrm{R}=$ Faktor erosivitas hujan.

$\mathrm{K}=$ Faktor erodibilitas tanah.

$\mathrm{LS}=$ Faktor panjang dan kemiringan lereng.

$\mathrm{CP}=$ Faktor penggunaan lahan dan pengolahan tanah.

1. Erosivitas Hujan (R)

Indeks daya erosi curah hujan (R) merupakan penjumlahan dan pekalian antara energi kinetik hujan dan intensitas hujan (Asak, 2014). Cara untuk menentukan nilai $\mathrm{R}$ dihitung dengan menggunakan persamaan:

$\mathrm{R}=\frac{\mathrm{EI}}{100} \times \mathrm{X}$ 
Keterangan:

$\mathrm{R}=$ Faktor erosivitas hujan.

$\mathrm{X}=$ Jumlah tahun atau musim hujan yang digunakan sebagaidasar perhitungan.

EI $=$ Energi kinetik dan intensitas hujan.

Cara menentukan EI menggunakan persamaan Bols Tahun 1978:

$\mathrm{EI}=6,12(R A I N)^{1.21}(D A Y S)^{0.47}$

$(M A X P)^{0.53}$

Keterangan:

EI = Energi kinetik dan intensitas hujan.

RAIN = Curah hujan bulanan $(\mathrm{cm})$.

$D A Y S$ = Jumlah hari hujan dalam satu bulan (hari).

$M A X P=$ Hujan harian maksimum pada bulan yang bersangkutan $(\mathrm{cm})$.

2. Erodibilitas Tanah $(\mathrm{K})$

Erodibilitas Tanah merupakan kepekaan partikel tanah terhadap pengikisan, pengelupasan, dan tansportasi partikel-partikel tanah disebabkan adanya energi kinetik hujan. Berikut merupakan tabel nilai erodibilitas tanah berdasarkan beberapa jenis tanah yang terdapat di Indonesia:

Tabel 1. Faktor Erodibilitas Tanah (K) Berdasarkan Jenis Tanah

\begin{tabular}{|l|l|l|}
\hline No & Jenis tanah & Faktor erodibilitas $(\mathbf{K})$ \\
\hline 1 & Latasol merah & 0.12 \\
\hline 2 & Latasol kuning & 0.26 \\
\hline 3 & Latasol & 0.31 \\
\hline 4 & Latasol coklat & 0.23 \\
\hline 5 & Regosol & 0.11 \\
\hline 6 & Litosol & 0.323 \\
\hline 7 & Gromosol & 0.27 \\
\hline 8 & Kambisol & 0.23 \\
\hline 9 & Mediteran & 0.8275 \\
\hline
\end{tabular}

(Sumber: Asdak ,2014)

3. Faktor Panjang (L) dan Kemiringan Lereng (S)
Faktor panjang lereng (L) ditentukan dari permukaan tanah yang dimana erosi sudah terjadi dan mengalami sedimentasi, atau sampai dengan aliran air di dasar permukaan tanah yang masuk dalam saluran. Umumnya untuk kemiringan lereng (S) diperlakukan sebagai rangkaian faktor seragam. Persamaan untuk menetukan LS melalaui Sistem Informasi Geografis berupa Arc-Gis menurut Perveen R \& Kumar U (2015) sebagai berikut:

$\mathrm{LS}=\left(\frac{\mathrm{FA} \times \mathrm{CS}}{2.21}\right)^{0.4} \times\left(\frac{(\text { sin }(\text { Slope }) \times 0.01745)}{0.09}\right)^{1.4}$

Keterangan:

$F A=$ Flow Accumulation

CS $\quad=$ Cell Size

Slope = Kemiringan lereng $(\%)$

4. Faktor Pengunaan Lahan dan

Pengolahan Tanah (CP)

Faktor Penggunaan Lahan (C) merupakan perbandingan antara erosi pada lahan yang ditanami suatu tanaman terhadap erosi pada tanah yang tidak ditanami tanaman dan di olah bersih (Arsyad, 2006 dalam Rohmaniah (2016)).

Faktor Pengolahan Tanah (P) merupakan perbandingan antara rasio tanah yang hilang tehadap konservasi tanah dengan tanpa usaha konservasi tanah.

Pada studi kasus ini faktor $\mathrm{C}$ dan $\mathrm{P}$ digabung menjadi faktor $\mathrm{CP}$. Nilai $\mathrm{CP}$ dapat dilihat pada tabel berikut:

Tabel 2. Faktor Penggunaan Lahan dan Pengolahan Tanah (CP)

\begin{tabular}{|l|l|l|}
\hline No & Penggunaan lahan & Faktor CP \\
\hline 1 & Pemukiman & 1 \\
\hline 2 & Kebun campuran & 0.05 \\
\hline 3 & Sawah tadah hujan & 0.19 \\
\hline 4 & Tegalan & 0.02 \\
\hline 5 & Semak belukar & 0.12 \\
\hline
\end{tabular}




\begin{tabular}{|l|l|l|}
\hline No & Penggunaan lahan & Faktor CP \\
\hline 6 & Hutan produksi & 0.03 \\
\hline 7 & Sawah & 0.02 \\
\hline
\end{tabular}

Sumber: RLKT (Rehabilitasi Lahan \&

Konservasi Tanah), 1986)

Tingkat Bahaya Erosi (TBE)

Erosi memiliki tingkatan bahaya yang bervariasi berdasarkan perbandingan antara erosi tanah aktual yang ada dengan erosi tanah yang telah ditoleransikan. Berdasarkan United States Departement of Agriculture (USDA), berikut merupakan klasifikasi tingkat bahaya erosi berdasarkan laju erosi yang dihasilkan:

Tabel 3. Klasifikasi Tingkat Bahaya Erosi

\begin{tabular}{|l|l|l|}
\hline $\begin{array}{l}\text { `Kelas } \\
\text { bahaya erosi }\end{array}$ & $\begin{array}{l}\text { Laju erosi } \\
\text { (ton/ha/tahun) }\end{array}$ & Keterangan \\
\hline I & $<15$ & $\begin{array}{l}\text { Sangat } \\
\text { ringan }\end{array}$ \\
\hline II & $15-60$ & Ringan \\
\hline III & $60-180$ & Sedang \\
\hline IV & $180-480$ & Berat \\
\hline V & $>480$ & $\begin{array}{l}\text { Sangat } \\
\text { Berat }\end{array}$ \\
\hline
\end{tabular}

(Sumber: Suripin, 2014)

\subsection{Hasil Sedimen}

Hasil sedimen (Sediment Yield) merupakan perhitungan besarnya sedimen yang mengendap di sungai maupun endapan yang ada di dalam saluran atau waduk yang berasal dari Daerah Tangkapan Air (DTA) yang diukur pada periode waktu tertentu (Supangat, 2014). Berdasarkan perhitungan laju erosi menggunakan metode USLE, maka dapat ditentukan nilai hasil produksi sedimen dengan persamaan:

$\mathrm{SY}=\mathrm{SDR} \times \mathrm{Ea}$

Keterangan:

SY = Nilai produksi sedimen (ton/ha).

SDR = Rasio penerimaan sedimen.

Ea = Laju erosi (ton/ha/th).

Berdasarkan persamaan di atas menentukan nilai produksi sedimen dipengaruhi oleh rasio besarnya tanah yang terkelupas oleh aliran sungai dan menuju waduk atau SDR. Nilai SDR dapat ditentukan dengan persamaan yang dikemukakan oleh Roehl (1962) sebagai berikut:

$\mathrm{SDR}=0.41 \times \mathrm{A}^{-0.3}$

Keterangan:

SDR = Rasio Penerimaan sedimen.

A $\quad=$ Luas DAS $\left(\mathrm{Km}^{2}\right)$.

Setelah diperoleh nilai Sediment

Yield (SY), maka dapat ditentukan untuk umur layanan waduk. Berikut persamaan untuk menentukan umur layanan waduk:

Berat Sedimen $=S Y \times$ A DAS

Keterangan:

Berat Sedimen $=$ Berat Sedimen (ton)

SY $\quad=$ nilai sediment yield (ton/ha)

A DAS $\quad=$ Luas DAS (ha)

$\mathrm{V}_{\text {sedimen }}=\frac{\text { Berat Sedimen }}{\text { pjenis tanah }}$

Keterangan:

$\mathrm{V}_{\text {sedimen }} \quad=\underset{\text { Volume }}{\text { Waduk }\left(\mathrm{m}^{3}\right)} \quad$ Sedimen

Berat Sedimen $=$ Berat Sedimen (ton)

$\rho_{\text {jenis tanah }}=\underset{\left(\text { ton } / \mathrm{m}^{3}\right)}{\text { Berat jenis tanah }}$

$\mathrm{Lt}=\frac{\mathrm{Vt}}{\text { Vsedimen }}$

Keterangan:

Lt $=$ Umur layanan waduk (tahun)

$\mathrm{Vt} \quad=$ Volume tampungan mati waduk $\left(\mathrm{m}^{3}\right)$

$\mathrm{V}_{\text {sedimen }} \quad=$ Volume Sedimen Waduk $\left(\mathrm{m}^{3}\right)$

\section{METODE PENELITIAN \\ Lokasi Penelitian}

Lokasi penelitian dilakukan di DAS Randugunting dari hulu DAS yang terletak pada Desa Gaplokan, Kabupaten Blora dengan koordinat 654'09,6"LS dan 
$111^{\circ} 17^{\prime} 40,0^{\prime \prime}$ BT hingga titik kontrol yang berada pada Waduk Randugunitng yang terletak pada desa kalinanas, kabupaten blora dengan koordinat 6052'19,14'LS dan $111^{\circ} 15^{\prime} 30,20^{\prime \prime}$ BT. Untuk lebih jelasnya lokasi dapat dilihar pada Gambar1.

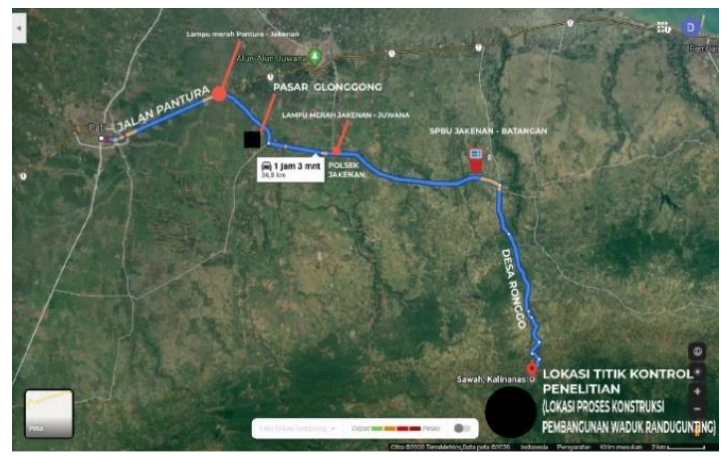

Gambar 1. Peta Lokasi DAS Waduk

\section{Diagram Alir}

Randugunting

Diagram alir penelitian yang digunakan dalam penelitian ini dapat dilihat pada Gambar 2.

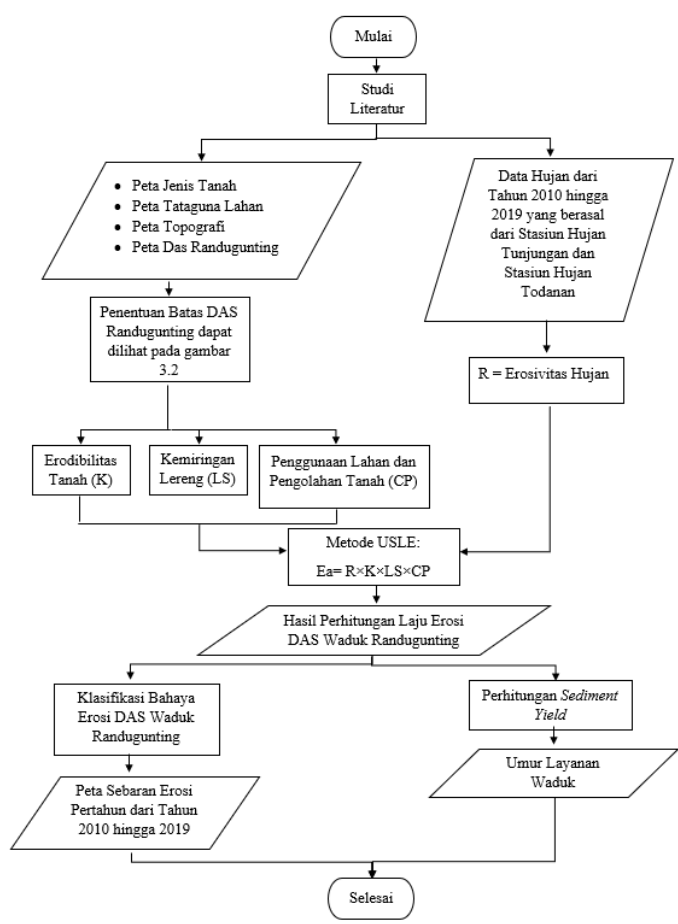

Gambar 2. Diagram Alir Penelitian
4. HASIL DAN PEMBAHASAN

Analisis Bobot Luasan Cakupan Wilayah untuk Stasiun Hujan

Analisis bobot luasan cakupan wilayah masing-masing stasiun Hujan (Stasiun Hujan Tunjungan dan Stasiun Hujan Todanan) DAS Waduk Randugunting digunakan metode Polygon Thiessen. Untuk lebih jelasnya dapat dilihat pada Gambar 3.

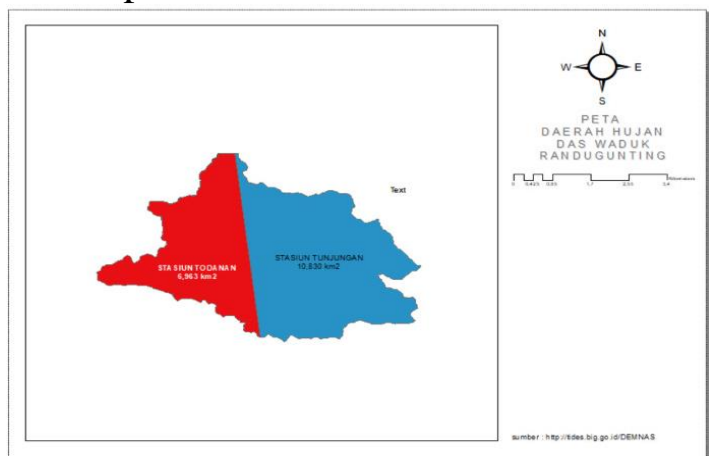

Gambar 3. Peta Polygon Thiessen DAS Waduk Randugunting

Analisis Erosivitas Hujan (R)

Faktor Erosivitas Hujan DAS Waduk Randugunting ( $\mathrm{Re}$ ) didapatkan dari persamaan 2 dan 3 dengan membutuhkan data hujan dari tahun 2010 hingga 2019. Berikut didapatkan pula peta erosivitas hujan DAS Waduk Randugunting per tahunnya dari tahun 2010 hingga 2019.

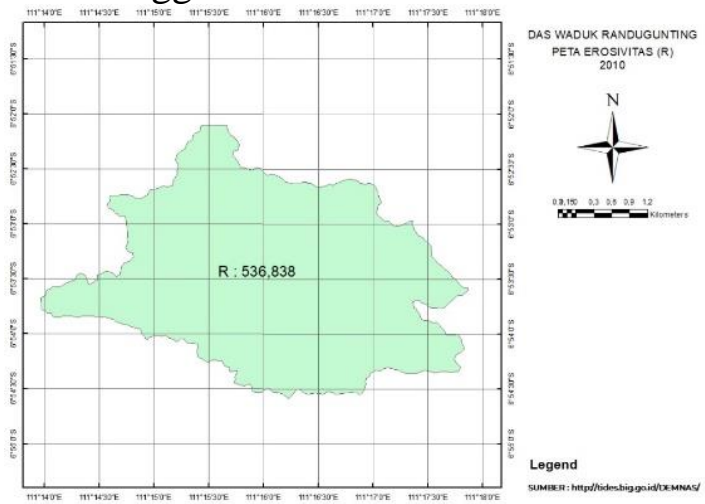

Gambar 4. Peta Faktor Erosivitas Hujan DAS Waduk Randugunting (Re) Tahun 2010 


\section{Analisis Erodibilitas Tanah (K)}

Faktor Erodibilitas tanah (K) didapatkan dari peta jenis tanah DAS Waduk Randugunting yang kemudian berdasarkan tabel 1. didapatkan peta faktor K. Untuk lebih jelasnya dapat dilihat pada Gambar 6.

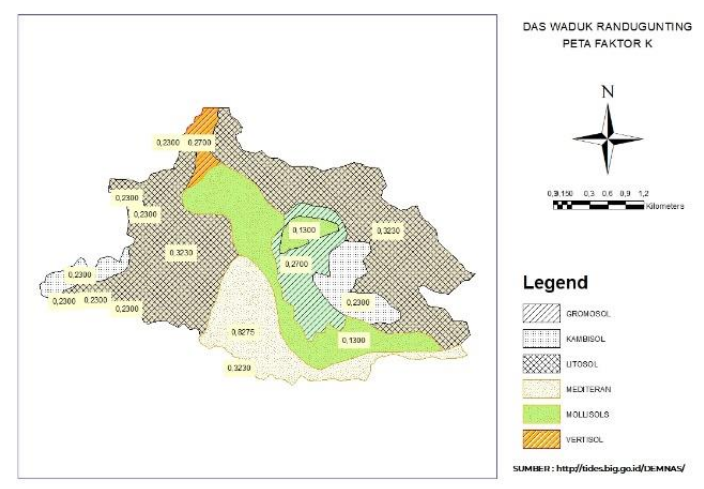

Gambar 6. Peta Faktor K DAS Waduk Randugunting

\section{Analisis Panjang dan Kemiringan Lereng (LS)}

Faktor panjang dan kemiringan lereng (LS) didapatkan dari persamaan 4 dibantu dengan aplikasi Arc-Gis. Berikut merupakan peta faktor LS yang dapat dilihat pada Gambar 7.

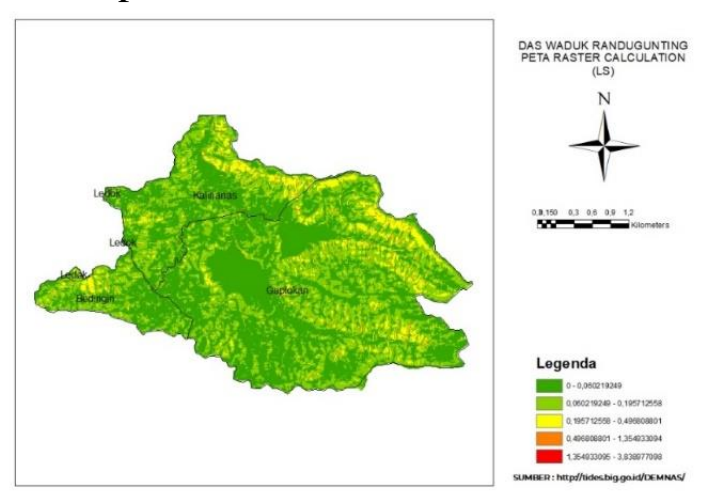

Gambar 7. Peta faktor LS DAS Waduk Randugunting

Analisis Penggunaan Lahan dan Pengolahan Tanah (CP)

Faktor Penggunaan Lahan dan Pengolahan Tanah (CP) didapatkan dari peta tata guna lahan DAS Waduk Randugunting yang kemudian berdasarkan tabel 2. didapatkan peta faktor CP. Untuk lebih jelasnya dapat dilihat pada Gambar 8. merupakan peta faktor LS yang dapat dilihat pada Gambar 7.

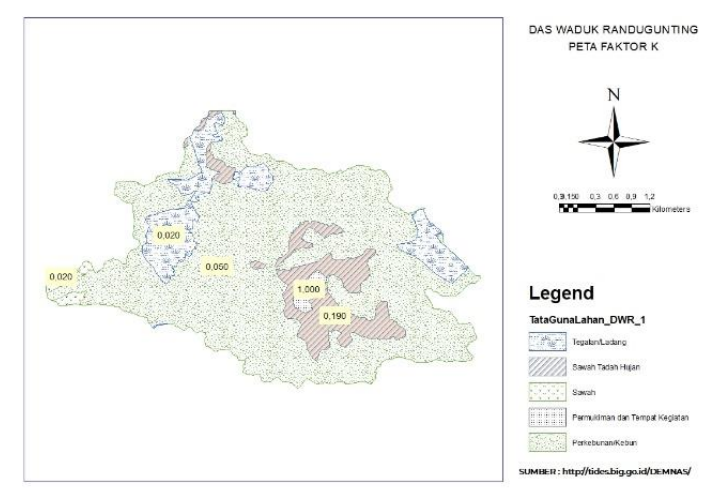

Gambar 8. Peta Faktor CP pada DAS

Waduk Randugunting

Analisis Perhitungan Laju Erosi (Ea)

Berdasarkan dari data-data

perhitungan maka didapatkanlah nilai untuk masing-masing faktor Re, K, LS, dan CP pada DAS Waduk Randugunting. Setelah didapatkan nilai faktor-faktor tersebut, maka dapat ditentukan untuk nilai laju erosi (Ea) DAS Waduk Randugunting berdasarkan persamaan 1 . dan didapatkan pula untuk Peta Sebaran Erosi DAS Waduk Randugunting per tahunnya dai tahun 2010 hingga 2019 berdasarkan tabel 3. Berikut meupakan contoh peta sebaran erosi DAS Waduk Randugunting tahun 2010.

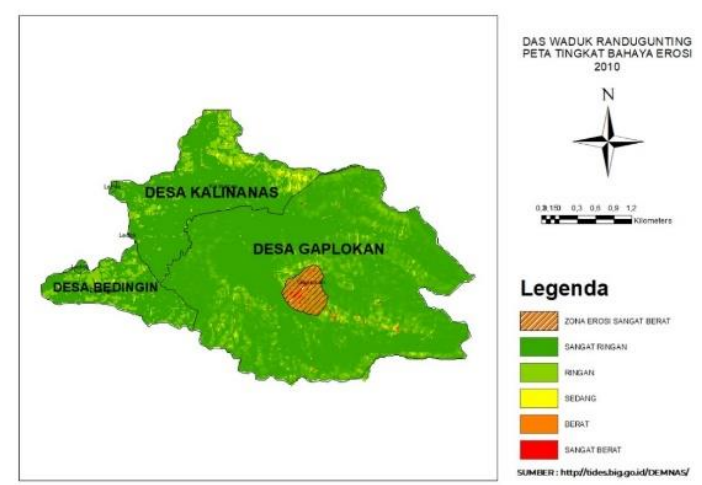

Gambar 9. Peta Sebaran Erosi Tahun 2010 
Berdasarkan peta sebaran erosi DAS Waduk Randugunting, maka didapatkan pula tabel klasifikasi tingkat bahaya erosi (TBE) DAS Waduk Randugunting pertahunnya dari tahun 2010 hingga 2019. Untuk lebih jelasnya dapat dilihat pada tabel 7 .

Tabel 7. Klasifikasi TBE pada DAS

Waduk Randugunting

dari Tahun 2010 hingga 2019

\begin{tabular}{|c|c|c|}
\hline Tahun & $\begin{array}{c}\text { Laju Erosi } \\
\text { (ton/ha) }\end{array}$ & $\begin{array}{c}\text { Tingkat Bahaya } \\
\text { Erosi }\end{array}$ \\
\hline 2010 & 107.600 & Sedang \\
\hline 2011 & 58.951 & Ringan \\
\hline 2012 & 58.672 & Ringan \\
\hline 2013 & 124.814 & Sedang \\
\hline 2014 & 153.848 & Sedang \\
\hline 2015 & 76.760 & Ringan \\
\hline 2016 & 149.637 & Sedang \\
\hline 2017 & 142.139 & Sedang \\
\hline 2018 & 97.998 & Sedang \\
\hline 2019 & 82.128 & Sedang \\
\hline Total & 1052.545 & \multicolumn{2}{|c}{} \\
\hline $\begin{array}{c}\text { Rata- } \\
\text { Rata }\end{array}$ & 105.255 & \\
\cline { 1 - 1 } & \multicolumn{2}{|c}{} \\
\cline { 1 - 2 } & &
\end{tabular}

Berdasarkan Tabel 5, maka dapat diolah menjadi grafik yang dapat dilihat pada Gambar 11.

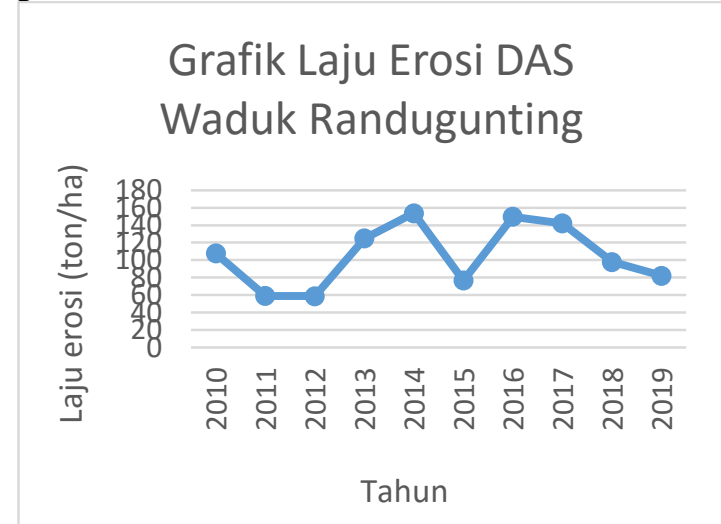

Gambar 11. Grafik Laju Erosi (Ea) DAS

Waduk Randugunting

\section{Analisis Hasil Sedimen}

Berdasarkan nilai laju erosi DAS

Waduk Randugunting maka dapat dilakukan perhitungan untuk mmenghitung nilai hasil sedimen
(Sediment Yield) berdasarkan persamaan 5 dan 6, maka didapatkan nilai hasil sedimen sebesar 7705.682 ton/ha. Setelah didapatkan nilai hasil sedimen, maka dapat juga dilakukan perhitungan untuk menghitung umur layanan waduk yaitu 35 tahun berdasarkan data teknis Waduk Randugunting dengan persamaan 7,8, dan 9.

\section{PENUTUP}

\subsection{Kesimpulan}

Berdasarkan hasil perhitugan laju erosi DAS Wadk Randugunting menggunakan metode USLE, maka ddidapatkan kesimpulan:

1.a. Luas DAS Waduk Randugunting yaitu sebesar $17.856 \mathrm{~km}^{2}$.

b. Besarnya nilai laju (Ea) DAS Waduk Randugunting nilai total laju erosi DAS Waduk Randugunting selama 10 tahun (2010-2019) sebesar 1052.545 ton/ha dan rata-rata pertahunnya sebesar 105.255 ton/ha/th.

c. Besarnya sedimentasi dari tahun 2010 hingga 2019 sebesar 7705.682 ton/ha. kemudian didapatkan pula untuk umur layanan waduk yaitu 35 tahun.

2.a. Potensi laju erosi berasal dari empat desa yaitu Desa Gaplokan dengan nilai erosi sebesar 69.995 ton/ha/th, Desa Kalinanas sebesar 27.730 ton/ha/th, Desa Bedingin sebesar 8.469 ton/ha/th, dan Desa Ledok sebesar 1.766 ton/ha/th.

b. Desa Gaplokan dominan penyumbang erosi terbesar yaitu sebesar 69.995 ton/ha/th dengan nilai persentase luas sebesar $65,051 \%$.

\subsection{Saran}

Berdasarkan analisis yang telah dilakukan dalam penelitian ini dapat diberikan beberapa saran, yaitu sebagai berikut: 
1. Pada Waduk Randugunting perlu upaya preventif terhadap sedimentasi yang tinggi seperti pengerukkan sedimen dan pembuatan Check Dam

2. Warga Desa Gaplokan perlu di beri pengetahuan mengenai besarnya laju erosi dan diajak untuk melakukan suatu program kerja bersama dalam upaya mencegah erosi.

3. Penelitian selanjutnya dapat dilakukan analisis perhitungan laju erosi dengan membandingkan anatara metode USLE dengan metode lainnya seperti metode MUSLE dan RUSLE.

\section{DAFTAR PUSTAKA}

Anonim. 2016. Sedimentasi Parah Lumpur di Waduk Gajah Mungkur Capai 6 Juta Meter Kubik dari situs internet: https://news.detik.com/berita/d3372323/sedimentasi-parah-lumpurdi-waduk-gajah-mungkur-capai-6juta-meter-kubik. Diakses pada tanggal 15 Mei 2019, pukul 19.00 WIB.

Anonim. 2019. Prediksi Musim Kemarau 2019 Lebih Kering dari Tahun Lalu dari situs internet:https://www.cnnindonesia.co $\mathrm{m} /$ nasional/20190704105626-20408974/bmkg-prediksi-musimkemarau-2019-lebih-kering-daritahun-lalu. Diakses pada tanggal 4 Juli 2019, pukul 17.00 WIB.

Asdak, Chay., (2014): Hidrologi dan Pengelolaan Daerah Aliran Sungai, Gadjah Mada University Press, Yogyakarta.

Bols, P. L., (1978): The Iso-Erodent Map of Java and Madura. Belgian
Technical Assistance Project ATA 105, Soil Research Institute, Bogor.

Peraturan Menteri Kehutanan Republik Indonesia. (2009): "Tata Cara Penyusunan Rencana Teknik Rehabilitasi Hutan Dan Lahan Daerah Aliran Sungai (RTKLHL-DAS). Menteri Kehutanan Republik Indonesia, Jakarta.

Rohmaniah, I. (2016): Analisis Laju Erosi dan Sedimentasi Waduk Wadaslintang Provinsi Jawa Tengah. Skripsi Program Studi Teknik Sipil, Universitas Negeri Jakarta. Jakarta.

Setyono, E., Ismijayanti, D., (2015): Prediksi Beban Sedimentasi Waduk Selorejo Menggunakan Debit Ekstrapolasi dengan Rantai MARKOV. Jurnal Teknik Sipil, Universitas Muhammadiyah Malang, 13-1.

Supangat, Agung B., (2014): Perhitungan Sedimen, Balai Penelitian Teknologi Kehutanan Pengelolaan DAS, Surakarta.

Suripin. (2014). Sistem Drainase Perkotaan yang Berkelanjutan. Penertbit ANDI Offset. Yogyakarta. 